\title{
FUNDAMENTAL RIGHTS AND THE OBLIGATION TO PUBLICLY DISCLOSE INFORMATION ON TAX STRATEGY
}

\author{
Adam Szymacha*
}

C $\mid$\begin{tabular}{l|l} 
Member since 2021 \\
P
\end{tabular}

cc) creative

\begin{abstract}
The aim of the article: The presented study concerns the problem of violations of fundamental rights caused by the law regulation contained in art. 27c of the Corporate Income Tax Act in Poland. This regulation provides obligation to publish information about introduced tax strategies. Yet, it may endanger many human rights and this article focuses on two of them - the right to remain silent, and the right of privacy. The aim of this article is to make an analysis of the standards presented by the Court of Justice of the European Union and the European Court of Human Rights. Additionally, the standard presented by the Polish Constitutional Court is presented.

Methodology: To decode these standards the comparative law method is used. Especially the case laws of these courts are presented and additionally, they are completed by the comparison of the acts that concern similar law institutions but come from different lawmakers.

Results of the research: The results of the study do not provide a clear answer. However, they do allow for an approximation of the issue of possible violations of fundamental rights by the analyzed regulation. It is very likely that the analyzed regulation violates the right to remain silent and it is even close to certainty that the analyzed laws violate the right to privacy. The problem is not only the interference in these rights, but in its character as well. Under certain circumstances, interference with fundamental rights is acceptable but must be proportionate. Examined laws are only explained in terms of budgetary balance and the academic world points out that the purpose of this type of regulation is mainly of administrative convenience. This is far too little to consider this interference with fundamental rights imperative.
\end{abstract}

Keywords: tax transparency, fundamental rights, proportionality, right to remain silent, right to privacy, tax strategies publication.

JEL Class: K38, H26.

\footnotetext{
* Doktorant, Szkoła Doktorska Nauk Społecznych, Uniwersytet Łódzki, e-mail: adam.szymacha88@gmail.com https://orcid.org/0000-0002-9372-9647
} 


\section{INTRODUCTION}

Article 27c of the Corporate Income Tax Act (hereinafter CIT) establishes the obligation to publicly disclose information on the implemented tax strategy. The subjective frame of this obligation is defined in Article 27b of the CIT. Pursuant to its meaning, taxpayers of corporate income tax who are also identified as tax capital groups or whose taxable income exceeded the equivalent of EUR 50 million per tax year, converted into PLN at the average exchange rate of the euro quoted by the National Bank of Poland on the last business day of the calendar year preceding the year in which individual taxpayer data was made public, are obliged to publish information on their tax strategy.

The very concept of a tax strategy is not entirely clear. Article 27c of CIT contains a definition by enumeration, but it is not a closed one. Pursuant to Article $27 \mathrm{c} \S 2$ of CIT, information on the implemented tax strategy must take into account the nature, type and size of business activity. For example, it is stated that this is information on tax risk management, i.e. on the number of submitted requests for individual interpretations of tax law and other similar acts on operative interpretation. Information on the implemented tax strategy should also include information on making tax settlements of the taxpayer in territories or countries applying harmful tax competition. Examples also include information on transactions with related parties, restructuring activities planned by the taxpayer, information on the implementation of tax obligations by the taxpayer, including transferred tax schemes, information on voluntary forms of cooperation as well as information on processes and procedures for managing the implementation of obligations under the tax law and ensuring their proper execution (Journal of Laws 1992, No. 21, item 86).

The obligation to publish information on the implemented tax strategy makes the publication addressed to the general public. The legislator introduced the new obligation in order to increase social control over the tax settlements of enterprises. This is another legal instrument to combat aggressive tax planning. However, one cannot remain indifferent to the fact that this is another potential infringement of taxpayers' right to privacy by forcing them to publish data related to their tax affairs. In addition, this obligation may violate the right to fair trial, in particular the right not to incriminate oneself. Thus, the purpose of this article is to analyze the matter of these fundamental laws and to check whether the obligation to publish tax strategy violates the abovementioned fundamental rights.

The aim of this paper is related to the obligation to publicly disclose information on the tax strategy and the law presentation in the light of fundamental rights such as the right to privacy and the right to fair trial. Special attention will be paid to the judgements that can help understand the possible violations of these fundamental rights. The article will verify the hypothesis according to which the 
legislator deliberately violates the taxpayers' right to privacy and a fair trial. The legislator is guided in this case only by two criteria. The first is care for state finances, the second is the convenience of administration. Violations of fundamental rights result from several factors. Firstly, sensitive data cannot be requested from the taxpayer. Such data for legal persons is financial data, including this related to tax risk management. Secondly, nothing protects a taxpayer from having published data used against him. Thirdly, any interference with fundamental rights should be proportionate, and the administration already has an appropriate tools to limit tax optimization. The legislator has chosen to introduce very restrictive solutions. However, these regulations are very unclear.

\section{MANDATORY DISCLOSURE IN THE CONTEXT OF FREEDOM FROM SELF-INCRIMINATION}

The first important problem is whether such an information solution is not in fact an obligation of self-donation. Already in the case of MDR duties, serious doubts have arisen in this respect, and against such a charge, at least according to some doctrine, MDR was protected by Article 86h of the Tax Ordinance (hereinafter $\mathrm{TO}$ ), according to which information provided in the report cannot constitute the sole basis for initiating proceedings in cases of tax offences. Although the report itself cannot become the basis for initiating proceedings, there is no obstacle to treat it in the same way as a notice of an offence. In any case, the financial pretrial investigation authority, having relevant information from the tax scheme at its disposal, will be able to seek to obtain other evidence to the taxpayer's disadvantage ${ }^{1}$.

Meanwhile, in the case of mandatory disclosure of a tax strategy, there is not even such a filter. Even in the justification, the legislator mentions that the published data ,may serve the authorities of the National Tax Administration in obtaining preliminary information about the activities of these taxpayers and possible reasons for differences in their tax settlements" (Explanatory Memorandum: 15-17). It should be noted that this provision creates a situation for the taxpayer in which they are supposed to partially relieve officials by providing them with preliminary information. As A. Mariański points out, the clerical factor dominates in the preparation of draft tax laws. This means that the administration transfers onto the taxpayer the obligation to provide information

\footnotetext{
${ }^{1}$ In one of its judgments, the Provincial Administrative Court in Warsaw stated that although the facts provided in connection with reporting tax schemes cannot constitute grounds for charges in criminal fiscal proceedings, ,nothing stands in the way of the information provided being the basis for initiating tax proceedings, as a result of which additional information will be obtained that will already allow criminal fiscal liability to be incurred" (Judgment of 29 April 2020 of the Provincial Administrative Court in Warsaw).
} 
which is needed by administration, but not necessarily serving the purpose of preventing tax avoidance. It is mainly about the convenience of the official (Marański and Michalak, 2020: 34). Tax legislation therefore increasingly ceases to be about balancing the interests of citizens with those of the state, and instead it begins to focus more and more on providing comfort to the tax administration (Mariański, 2019: 34).

It follows, therefore, that the taxpayer is expected to provide convenient information to the tax administration and nothing protects them from possible negative consequences of providing this information. However, it should be mentioned here that the standard of protection of the right to silence is complex.

It seems that both the Court of Justice (one of the courts of the EU - see also art. 19(1) Treaty of European Union, OJ.C 326 , 26/10/2012 P. 0001-0390) and the European Court of Human Rights (hereinafter the Court) are of the opinion, that the full right not to provide documents against oneself is only available to individuals in criminal proceedings (Hofmański and Wróbel, 2010: 403). The protection of this right is derived from the right to a fair trial contained in Article 6 of the European Convention on Human Rights. The right to silence is also contained in the Charter of Fundamental Rights of the European Union ${ }^{2}$. Freedom from self-incrimination is a component of a fair trial as it is linked to the presumption of innocence (Kowalik-Bańczyk, 2012: 340), which is also a rule of evidence that places the burden of proof on the public prosecutor, while relieving the accused of it (Kowalik-Bańczyk, 2012: 341; Hofmański and Wróbel, 2010: 403).

Therefore, given the personal scope of the obligation to publish information on tax strategy, it seems that the right to silence does not apply. This is because the very systematics of the provision placed in the Corporate Income Tax Act seems to exclude the nemo tenetur principle, applicable only to natural persons. This logic is also presented in the explanatory memorandum, where it is indicated that information on the implemented tax strategy should include information on all taxes, and the very placement of the provision results from the ,subjective approach - i.e. imposing the projected obligation only on selected corporate income taxpayers" (Explanatory Memorandum: 49).

${ }^{2}$ Although the principle of nemo tenetur is also recognised under the Charter of Fundamental Rights, the fundamental rights protected by the Convention are also general principles of the Union. The right not to be held against oneself is also protected under the Charter of Fundamental Rights, whose provisions cannot be interpreted in such a way as to confer weaker protection for fundamental rights. C-481/19 DB v Commissione Nazionale per le Società e la Borsa (Consob) ECLI:EU:C:2021:84, at 36. 
Article $27 \mathrm{~b} \S 2$ point 1 and 2 CITU establishes the circle of obliged entities. Therefore, these are:

- tax capital groups, regardless of the amount of revenue achieved;

- taxpayers other than tax capital groups, in which the value of revenue earned in the tax year referred to in Art. 27b par. 1 of the CIT Act exceeded the equivalent of EUR 50 million converted into PLN according to the average exchange rate of the euro announced by the National Bank of Poland on the last working day of the calendar year preceding the year in which individual taxpayer data was made public.

Theoretically, therefore, the right to remain silent does not apply to entities obliged to publish information on tax strategy. However, there are categories of cases in which the right of silence is not absolute, but is granted to collective entities. In this respect, however, there are important differences between the standard of protection afforded by the Court and the Court of Justice.

The Court of Justice expressed the standard of protection of the nemo tenetur principle in the Orkem ruling (C-374/87 Orkem, item 30). According to this principle, a partial right not to incriminate oneself is granted in antitrust proceedings before the Commission, although the sanction in such proceedings may be very severe. According to the Court of Justice, the mere fact of being obliged to provide already existing documents or to answer a factual question does not violate this rule (Turno, 2009: 36). This is therefore a fairly low standard of protection. The right therefore includes the right not to plead guilty, not to remain silent as to the facts. This position was later reiterated by the EU General Court on the grounds that granting undertakings the right to remain silent would go beyond the rights of the defense and would also constitute an unjustified obstacle to the enforcement of competition law (T-112/98 Mannesmannröhren-Werke AG v Commission, item 62). However, it should not be forgotten that what is at stake here is a balancing of values that are important in the European Union, namely the right to a court and the principle of fair competition.

However, it is not entirely clear which values are so important that they justify obliging taxpayers to provide publicly to the tax authorities information that can be used against taxpayers. Of course, a certain value of protecting the tax base must be recognized. The legislator readily invokes the protection of budget balance and the sealing of the tax system. One can get the impression that this has become a convenient and abused justification for introducing further restrictive regulations, which interfere too deeply and disproportionately with taxpayers' rights. However, measures aimed at improving the fiscal effectiveness of taxes should not be associated with negative consequences for the taxpayer. It may be stated that in the situation when new obligations are too labor-intensive, costly or hinder the taxpayer's daily economic practice, or force a change of legal behavior 
or reduction of activity. These are justified attitudes to conclude that the legislator does not protect honest taxpayers sufficiently (Drywa, 2020: 16-17).

However, the problem lies elsewhere. The legislator himself notes that „the introduction of the proposed solutions is another step towards increasing the transparency of tax settlements of the largest corporate income taxpayers" (Explanatory Memorandum: 16). Indeed, there are already many information tools at the disposal of tax administration. In addition to the MDR duties, one can mention publishing, pursuant to Article $27 \mathrm{~b}$ CITU, basic data of entities from their tax returns, such as the amount of revenues, costs, income or loss, tax base and tax due (Journal of Laws 1992, No. 21, item 86). Other anti-optimization tools with the general anti-avoidance clause contained in Article 119 of the TO should not be forgotten either. Therefore, does the introduction of another reporting obligation mean that the previously introduced tools are ineffective? This question is justified insofar as taxpayers have grounds to expect some reasonable limit of obligations motivated by care for protection of the tax base.

However, whatever importance one places on the value of protecting the tax base, several problems need to be considered. First, it is difficult to accept that an obligation to provide easy information to the tax authorities is proportionate to the infringement of the subject's right to remain silent. As shown above, a similar effect can be achieved with other tools, which are moreover far less interfering with the right to court. However, these tools are less convenient for officials. Secondly, when analyzing the new regulation against the background of the EU antitrust proceedings, it should be noted that even in these specific proceedings limiting the freedom against self-incrimination, there is no pan-European order to publish facts that may prove companies' participation in a cartel. In other words, while the Commission has considerable powers vis-à-vis suspected parties, it must itself first establish suspicion and initiate proceedings. The publication of data under Article 27c CIT, seen as providing officials with data on the basis of which tax proceedings can be initiated, seems an excessive interference with the freedom from self-incrimination.

However, even in the case of proceedings initiated by the Commission, the rules of evidence are not entirely arbitrary. It is recognized that questions about objective facts relating to the circumstances of a particular meeting (Turno, 2009: 37) are permitted, and sometimes a question may be asked about the subject matter or theme of the meeting. Questions suggesting an answer or requiring a value judgement may not be asked. The undertaking is not obliged to answer questions of fact, but the provision of documents is usually understood to mean copies of invitations to meetings and minutes, reports and notes of meetings (Turno, 2009: 38). This approach is based on the fact that the Commission has the burden of proving the existence of an infringement (Kowalik-Bańczyk, 2012: 384, 385). 
The Commission has also been granted the right to ask questions about the fact of meetings with other alleged cartel members, but the EU General Court has questioned these questions as regards the purpose of the meeting and the decisions taken (T-112/98 Mannesmannröhren-Werke AG v Commission). Questions concerning the interdependence of agreements entered into by an undertaking are inadmissible (Kowalik-Bańczyk, 2012: 386). As a result of further clarification of the Orkem rule (C-238/99P Limburgse Vinyl Maatschappij, item 274) it was held that the freedom from self-incrimination applies to coercive questions under penalty (Kowalik-Bańczyk, 2012: 386). In conclusion, according to the Court of Justice, the right of silence in antitrust proceedings is not absolute, but it is still enjoyed by collective entities and therefore the burden of proof remains with the public prosecutor. This means that it is the public prosecutor who must make the first impulse to conduct the proceedings and gather evidence.

Slightly more power is given to individuals by the Court on the nemo tenetur principle. In the Funke judgment (Application no. 108/28/84 in Funke v France, par. 41-44), the Court held that the prosecutor should prove the charge against the accused without the possibility of coercion (Application no. 19187/91 Saunders $\mathrm{v}$ the United Kingdom, par. 68). However, such protection is linked to the determination of the threat of a criminal sanction (Kowalik-Bańczyk, 2012: 342, 343). In administrative proceedings, coercion of evidence is allowed. It should be noted that tax law is the most similar to administrative law, which is evidenced by the similar method of regulation of legal relations which are the subject of the constructed norms (Mariański and Michalak, 2020: 35). In Allen and Weh (Decision on the Inadmissibility of Application No. 76574/01 Allen v the United Kingdom; Application No. 38544/97 Weh v Austria, par. 39; following KowalikBańczyk, 2012: 343), the Court accepted that the freedom from self-incrimination does not apply to the provision of financial statements to the tax authorities, as long as there is no criminal sanction behind it. In the case of the compulsory publication of information on the tax strategy pursued, the legislator decided not to exclude criminal sanctions in any way.

\section{RIGHT TO PRIVACY}

In the sphere of the right to privacy derived from Article 8 of the European Convention on Human Rights (Journal of Laws 1993, No. 61, item 284) (hereinafter the Convention) and Article 7 of the Charter of Fundamental Rights (OJ C 326/391. EU C 326/391) (hereinafter the Charter), it is no longer in doubt today that collective entities also enjoy this right. However, the evolution of this right was associated at first with the extension of the right to privacy to the economic activities of individuals (Vedsted-Hansen, 2014: 154, 157). Influenced 
by the case law of the Strasbourg Court, the Court of Justice has adopted an approach to privacy protection that does not distinguish between private and business entities. In Roquette Frères SA (C-94/00 Roquette Frères SA), it was held that the need to protect against arbitrary or disproportionate interference by a public authority with a person's private activities, whether natural or legal, is a general principle of Community law. In the Nexans France SAS v Commission judgement (T-135/09 Nexans France SAS and Nexans SA v Commission), the Court established the need for protection against arbitrary and disproportionate interference by the authorities, irrespective of legal subjectivity, arising from the principles of EU law and Article 7 of the Charter (Vedsted-Hansen, 2014: 154).

With its judgment in Société Colas Est v France (Application no. 37971/97 Société Colas Est v France), the Court also developed privacy protection for legal persons. It then granted privacy protection under Article 8 of the Convention during administrative control. In doing so, it pointed out that any limitation of this right based on the public interest must be accompanied by safeguards that effectively protect against abuse (Vedsted-Hansen, 2014: 158). However, the right to privacy has not been equalized in relation to natural and legal persons. Limitations to the protection of this right in relation to legal persons arise from their nature, as some abuses can only occur in relation to natural persons (VedstedHansen, 2014: 159). According to the Court of Justice, the protection of the right to privacy in publishing data of grant beneficiaries only covers data of individuals (Joined Cases C-92/09 and C-93/09 Volker und Markus Schecke GbR and Hartmut Eifert v Land Hessen, pos. 87). Furthermore, the relevant laws should define precisely the subject and object of the interference, as well as a system of effective and adequate safeguards and appropriate supervisory authorities (Sobczak, 2013: 277). The best supervision, in the opinion of the Court, is judicial supervision. It is the Court's view that even in the case of combating the most serious crimes, one must always take into account the impact that possible interference may have on fundamental rights (Application No. 623332/00 Segerstedt-Wiberg v Sweden). Legal precision is also an important issue here. In the Funke, Cremieux and Miailhe cases, the Court pointed out that gaps in the law and the lack of precision of the provisions governing searches constitute grounds for finding a violation of the right to privacy (Nowicki, 2010: 559).

However, even for the most serious offences, the Court recognizes that interference with the right to privacy must be proportionate (Application No. 623332/00 Segerstedt-Wiberg v Sweden). This means that the legitimate purpose of transferring information may justify interference with the right to privacy only up to certain limits. However, combating tax evasion and ensuring budgetary sustainability do not seem to be sufficient motivations for establishing further information obligations. 
Interference with the right to privacy must meet certain requirements. The case law of the Court of Justice emphasizes the principle of necessity or otherwise of indispensability (C-468 Asociación Nacional de Establecimientos Financieros de Crédito (ASNEF) and C-469/10 Federación de Comercio Electrónico y Marketing Directo (FECEMD) v Administración del Estado). The question must be asked whether these objectives could not be achieved using less intrusive methods. As already mentioned, tax authorities already have a sufficient arsenal of anti-optimization tools at their disposal. The Court of Justice has allowed the creation by public authorities of automated databases on salaries above a certain threshold (C-465/00 Rechnungshof v Österreichischer Rundfunk). However, the information collected was not universally transmitted and concerned only employees of public entities. The concern to ensure efficiency in public spending and to keep public sector salaries within reasonable limits justifies, in the view of the Court of Justice, a certain interference with the right to privacy. However, the content of the data processed is not exempt from the requirement of necessity (C-524/06 Heinz Hubner v Bundesrepublik Deutschland).

The Court of Justice has also examined the mandatory supply of data by authorized economic operators under customs law. Deutsche Post, in order to maintain this status in customs law, was obliged to provide the TIN numbers of its managerial staff. This data was to allow verification of whether an authorized economic operator had committed a serious infringement of tax or customs legislation or an economic crime. The Court of Justice stated that the data processed should be adequate, relevant and limited to what is necessary for the purposes for which the personal data are collected (C-496/17 Deutsche Post AG v Hauptzollamt Köln).

As far as the Convention standard of protection of the right to privacy is concerned, it should be mentioned that the admissibility of interference with rights and freedoms is assessed using the criteria of lawfulness and proportionality. Thanks to the formulation of the rights and freedoms contained in Articles 8-11 in general language, the Court has a wide field to determine their substantive content. This means that in the Court's jurisprudence, the Convention's rights and freedoms have been interpreted broadly, going well beyond the original intentions of the Convention's drafters. Against this background, three general principles for the application of the Convention have also taken shape:

- The Convention has been considered a living instrument, constantly adapted to the changing cultural, social and political context.

- In addition to the negative obligations, the Convention entails positive obligations, understood as the obligation to create solutions that make the exercise of rights and freedoms a reality.

- It is acknowledged that the Convention sets only a minimum standard and nothing prevents individual states from raising this standard (Garlicki, 2011: 482). 
The right to privacy in the context of the universal obligation to provide information was also the subject of a ruling of the Constitutional Tribunal (hereinafter: the CT; judgment of the Constitutional Court K41/02 OTK-A 2002, No. 6, item 83). It was then held that the regulation establishing a general obligation to submit asset declarations does not meet the requirements set out in Article 31(3) of the Constitution (the principle of proportionality), as these obligations are not necessary to achieve a constitutionally justified objective, and that ,the intended potential and hypothetical goals of streamlining the work of the tax apparatus remain in clear disproportion to the burden that the necessity to collect the necessary data, prepare declarations, assess all of the assets and the high (punishable) risk of their subjective unintentional unreliability pose to natural persons". The Court also pointed out that the use of legal tools to optimize tax liabilities does not constitute a crime.

The CT also raised the issue of the informational autonomy of individuals, which is derived from the right to privacy. It means, the right to decide for oneself whether to disclose information concerning one's person to others, as well as the right to exercise control over such information if it is in the possession of other entities" (Judgment of the CT, U 3/01, OTK ZU No. 1/2002, item 3). As noted by the $\mathrm{CT}$, the right to privacy and the related informational autonomy are so important that even in very exceptional situations, the legislator may not relax the prerequisites, the fulfilment of which would allow an intrusion into the sphere of private life without being exposed to the charge of unconstitutional arbitrariness (Judgment of the CT, K41/02 OTK-A 2002, item 26). As the CT emphasized, considerations of convenience for the authorities cannot justify the infringement of informational autonomy. It may only be infringed if this is ,necessary in a democratic state under the rule of law" (Judgment of the CT, K41/02 OTK-A 2002, item 26).

The CT assessed the wide-ranging information obligation as convenient for officials rather than really necessary. The ruling also analyzed the issue of the burden of proof, as well as the necessity of the duty of proof. The first premise of proportionality is the necessary premise (conditio sine qua non). Therefore, as long as the tax authorities have other tools at their disposal to identify tax irregularities, there is no sufficient justification for a general information obligation. These tools do not have to be convenient or quick (Judgment of the CT, K41/02 OTK-A 2002, item 26). The information available to the tax authorities does not have to be obtained automatically from the „first hand". It is sufficient that the authorities can carry out an appropriate procedure to obtain the required information (Judgment of the CT, K41/02 OTK-A 2002, item 26). The second premise, however, is that interference in the sphere of rights and freedoms must be the least severe measure for the entity whose rights and freedoms are infringed. 
The CT also commented on the general standard of privacy contained in Article 47 of the Polish Constitution. Although it may seem that only natural persons are entitled to this right, the guarantees granted by Article 47 also cover organizational units. When examining the compatibility of interference with bank secrecy with the Constitution of the Republic of Poland, the CT acknowledged: „every taxpayer who engages in economic activity" the right to a certain privacy of this activity, as long as it is not aimed at concealing criminal activity or evading certain public-legal obligations (Judgment of the CT, K 21/96, OTK 1997, No. 2, item 23). By its content, on the other hand, Article 47 of the Constitution of the Republic of Poland includes the protection of information concerning a given person, as well as enabling this person to decide on the scope and range of making available and communicating information about their life to others (Safjan and Bosek, 2016: 11-12).

\section{CONCLUSIONS}

When it comes to freedom from self-incrimination, the matter does not seem simple or finite. The Convention standard of protection extends to any person accused of a criminal act. It is a protection which is not subject to exceptions, but which is granted only to natural persons. In view of the fact that the provision in question concerns corporate taxpayers, it would seem that this standard will not apply in this case, at least until the Court's line of case law changes. It must not be forgotten, however, that fundamental rights, guaranteed by the Convention and resulting from the constitutional traditions common to the Member States, are part of the EU law, as general principles of law are also general principles of the EU (C-481/19 DB v Commissione Nazionale, pos. 36). Moreover, the Convention also affects Union law in such a way that all the Member States are also parties to the Convention. The Convention is also referred to in Article 52(3) of the Charter of Fundamental Rights of the European Union (OJ EU C 326/391). According to its wording, ,insofar as this Charter contains rights which correspond to rights guaranteed by the ECHR, the meaning and scope of those rights shall be the same as those laid down by the Convention. This provision shall not prevent Union law providing more extensive protection". It follows that the minimum standard of protection of fundamental rights is set by the Convention. There is a feedback loop between the Charter and the Convention, in that the dynamic interpretation of the Convention influences the interpretation of the provisions of the Charter, but the same phenomenon also occurs in the reverse direction (Górski, 2018: 92-93).

Meanwhile, the standard of protection of the nemo tenetur rule developed by the Court of Justice also covers legal persons. Of course, this is not an absolute protection, but it seems that it is sufficient protection for Article 27c of the CITU 
to be considered a violation of the right of silence. However, the problem of application of the Luxembourg standard arises, as the Polish regulation is an original idea of the Polish legislator and does not constitute implementation of the European Union law. On the other hand, as it has already been mentioned, the interpretation of the Charter also influences the interpretation of the Convention, which allows certain assumptions to be made for the future. However, irrespective of the issue of the applicability of the standard of protection set by the Charter and the Convention, nothing stands in the way of using these interpretations to reconstruct the content of the right to silence in the domestic legal order. While the issue is not entirely resolved, a regulation forcing taxpayers to disclose sensitive tax data to the public should raise serious questions.

It is somewhat easier to formulate conclusions about a possible right to privacy. Both the CT and the Court of Justice grant protection of this right to all entities, regardless of legal status. Obviously, the nature of data subject to privacy will be different for an individual and for legal persons. The standard of protection of the right to privacy appears to be essentially uniform when it comes to the protection of an individual's economic data. Indeed, in the situation of a legal person carrying out economic activities, economic data seems to be the main data to be protected.

It does not seem that the institution in question is 'necessary in a democratic state under the rule of law'. At this point, it is worth considering whether the previous regulations aimed at tightening the tax system have not exhausted the need to impose new information obligations on taxpayers.

The obligatory publication of information on the implemented tax strategy is also not the least burdensome for obliged entities. The legislator modelled the new regulations on Australian and British solutions. It should not escape its attention that a similar solution already exists in Australia as a completely voluntary one. The Australian legislator pursues the goal of increasing public awareness of tax transparency through the voluntary TTC (Tax Transparency Code) reporting system. Meanwhile, the Polish legislator does not even hide the fact that data published in accordance with Article $27 \mathrm{c}$ of the CITU may serve the tax administration in „obtaining preliminary information on the activities of such taxpayers and on possible reasons for differences in their tax settlements". Thus, the actual purpose of the new regulation is to force taxpayers to bail out officials, which does not meet the necessary premise. The cited analysis of the standards of protection of the right to privacy therefore rules out the proportionality of the interference with this right by Article 27c of the CITU. Nor does it appear that the cyclical imposition of ever new information burdens on taxpayers is appropriate in a democratic state under the rule of law, since everyone has the right to expect a reasonable limit of such obligations. Such obligations should not interfere disproportionately with taxpayers' fundamental rights, but neither should they 
hinder them too much in their normal economic activities. Meanwhile, the legislator seems to forget the basic principles it should apply to taxpayers, focusing only on its own interests and the convenience of the tax administration.

\section{REFERENCES}

Act of 15 February 1992 about corporate income tax, Journal of Laws 1992, No. 21, item 86.

Application no. 108/28/84 Funke v France.

Application no. 19187/91 Saunders v United Kingdom.

Application no. 37971/97 Société Colas Est v Francji.

Application no. 38544/97 Weh v Austria.

Application no. 623332/00 Segerstedt-Wiberg v Sweden.

Charter of Fundamental Rights of the European Union, OJ. EU C 326/391.

Convention for the Protection of Human Rights and Fundamental Freedoms, Journal of Laws 1993, No. 61, item 284.

Decision on the inadmissibility of application No. 76574/01 Allen v United Kingdom.

Drywa, A. (2020). Uszczelnianie systemu podatkowego a problemy, których nie możemy tracić z pola widzenia. Rozważania na przykładzie prawa podatnika do prywatności. W: D.J. Gajewski, red., Uszczelnienie systemu podatkowego w Polsce. Warszawa: Wolters Kluwer.

Explanatory Memorandum to the Government Bill amending the Personal Income Tax Act, the Corporate Income Tax Act, the Act on Lump Sum Income Tax on Certain Incomes Earned by Natural Persons and certain other acts, print No. 642.

Garlicki, L., red. (2010). Chapter I, Prawa i wolności, Art 8. W: L. Garlicki, red., Konwencja o Ochronie Praw Człowieka i Podstawowych Wolności, Tom I, Komentarz do artykułów 1-18. Warszawa: C.H. Beck.

Górski, M. (2018). Karta Praw Podstawowych UE jako living instrument. W: J. Barcik, M. Półtorak, red., Unia Europejska w przededniu Brexitu. Warszawa: C.H. Beck.

Hofmański, P. and Wróbel, A. (2010). Art. 6 Prawo do rzetelnego procesu sądowego. W: L. Garlicki, red., Konwencja o Ochronie Praw Człowieka i Podstawowych Wolności, Tom I, Komentarz do artykułów 1-18. Warszawa: C.H. Beck.

Joined cases C-92/09 i C-93/09 Volker und Markus Schecke GbR i Hartmut Eifert v Land Hessen, ECLI:EU:C:2010:662.

Judgement C-238/99P Limburgse Vinyl Maatschappij and others v Commision, ECLI:EU:C:2002:582.

Judgement C-465/00 Rechnungshof v Österreichischer Rundfunk, ECLI:EU:C:2003:294.

Judgement C-468 Asociación Nacional de Establecimientos Financieros de Crédito (ASNEF) and C-469/10 Federación de Comercio Electrónico y Marketing Directo (FECEMD) v Administración del Estado, OJ EU 25/18, CELEX: 62010CA0468.

Judgement C-496/17 Deutsche Post AG v Hauptzollamt Köln, ECLI:EU:C:2019:26.

Judgement C-524/06 Heinz Hubner v Bundesrepublik Deutschland, ECLI:EU:C:2008:724.

Judgement C-94/00 Roquette Frères SA v Directeur général de la concurrence, de la consommation et de la répression des fraudes, ECLI:EU:C:2002:603.

Judgment of 29 April 2020 of the Provincial Administrative Court in Warsaw, III SA/WA2402/19. Judgment of the Constitutional Tribunal of 19 February 2002, U 3/01, OTK ZU No. 1/2002.

Judgment of the Constitutional Tribunal of 20.11.2002 K41/02 OTK-A 2002.

Judgment of the Constitutional Tribunal of 24.6.1997, K 21/96, OTK 1997, No. 2.

Judgment of the Constitutional Tribunal of. 20.11.2002 K41/02 OTK-A 2002, No. 6. 
Judgment of the Court of Justice of the EU C-481/19 DB v Commissione Nazionale per le Società e la Borsa (Consob) ECLI:EU:C:2021:84.

Judgment of the Court of Justice of the EU of 18.10.1989, C-374/87 Orkem, ECLI:EU:C:1989:387. Judgment T-112/98 Mannesmannröhren-Werke AG v Commission, ECLI:EU:T:2001:61.

Judgment T-135/09 Nexans France SAS and Nexans SA v Commission, ECLI:EU:T:2012:596.

Kowalik-Bańczyk, K. (2012). Prawo do obrony w unijnych postepowaniach antymonopolowych. W kierunku unifikacji standardów proceduralnych $w$ Unii Europejskiej. Warszawa: Wolters Kluwer.

Mariański, A. (2019). Polska legislacja podatkowa - dokąd zmierzamy? W: J. Szołno-Koguc, red., Ewolucja roli podatków i systemów podatkowych we współczesnych gospodarkach. Lublin: Wydawnictwo UMCS.

Mariański, A. and Michalak, A. (2020). Wprowadzenie obowiązku raportowania schematów podatkowych. Analiza prawno-konstytucyjna. Przeglad Podatkowy, 8.

Nowicki, M.A. (2010). Wokót Konwencji Europejskiej, Komentarz do Europejskiej Konwencji Praw Człowieka. Warszawa: Wolters Kluwer.

Safjan, M. and Bosek, L. (2016). Art 47, Zasada ochrony życia prywatnego. W: M. Safjan, L. Bosek, red., Konstytucja RP. Tom I. Komentarz do art. 1-86. Warszawa: Wolters Kluwer, Legalis [Accessed 1.06.2021].

Sobczak, J. (2013). Tytuł II: Wolności, Art. 8 [Ochrona danych osobowych]. W: A. Wróbel, red., Karta Praw Podstawowych Unii Europejskiej, Komentarz. Warszawa: C.H. Beck.

Treaty of European Union, OJ.C 326 , 26/10/2012 P. 0001-0390.

Turno, B. (2009). Prawo odmowy przekazania informacji służącej wykryciu naruszenia reguł konkurencji w orzecznictwie Europejskiego Trybunału Sprawiedliwości. Ruch Prawniczy, Ekonomiczny i Socjologiczny, LXXI(3).

Vedsted-Hansen, J. (2014). Article 7 - Respect for Private and Family Life (Private Life, Home and Communications). W: St. Peers, T. Hervey, J. Kenner and A. Ward, red., The EU Charter of Fundamental Rights, A Commentary. Oxford: Beck/Hart. 